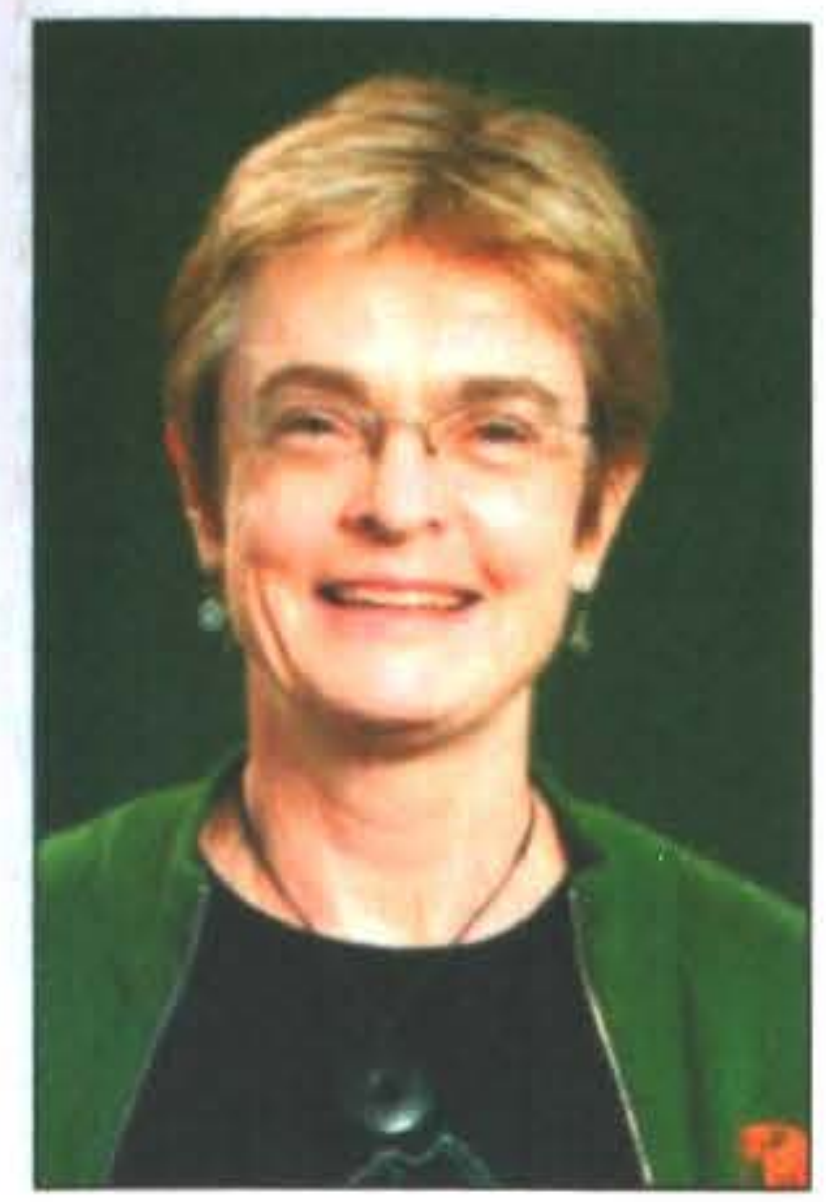

\title{
NEW ZEALAND'S WORKERS' \\ COMPENSATION: \\ HOW WILL IT FARE IN A \\ CHANGING ENVIRONMENT?
}

\author{
Nadine McDonnell \\ School of Business \\ Auckland University of Technology
}

\begin{abstract}
The Woodhouse Report and the subsequent 1972 Accident Compensation Act was revolutionary. The right to sue to recover compensatory damages arising directly or indirectly out of personal injury was abolished, although there was still the provision to take an action for damages in a court outside of New Zealand. Since then, workers' compensation in New Zealand has evolved and metamorphosed into our current scheme. However, the effectiveness of workers' compensation schemes in terms providing protecting injured workers and their dependents has been eroded over the years. This paper not only provides a brief background to the current system but also explores the notion that if the current workers' compensation scheme is failing New Zealand workers, perhaps it is time to look at other alternatives. In particular, the tort system of law may afford workers fairer compensation and may spur employers to provide healthy and safe working environments.
\end{abstract}

\section{Introduction}

Most industrialised countries, including New Zealand, introduced workers' compensation schemes in the closing years of the $19^{\text {th }}$ and early years of the $20^{\text {th }}$ centuries. The early workers' compensation schemes were seen as experiments in social welfare and over the past 100 years the experiment has continued. From time to time the schemes have undergone major reforms, notably the introduction of the New Zealand Accident Compensation Act in 1974 which, based on an earlier report by Judge Woodhouse, created the distinctive universal, no-fault injury and rehabilitation compensation scheme that remains today. However, the New Zealand Accident Compensation scheme, which became know as "the great experiment", has had it critics. On one hand employer groups complain that the costs are out of control and harming productivity and competitiveness. On the other hand workers and trade unions complain that the sick and injured continue to bear too much of the costs of dangerous or unhealthy work conditions and argue that injured workers and their families are impoverished by injury and disease. And those who deal with workers compensation complain that the system has become complex, large and bureaucratically impersonal. The question is whether the time has come to end the experiment or should the workers' compensation remain in its preset form?

The purpose of this paper is to argue that if the workers' compensation systems have failed to meet the promise of the early architects of the scheme, then perhaps the experiment should end. The question would no longer be how best to fix or reform workers' compensation, but how to replace it. However, it is necessary to first remind ourselves of the rationale behind the New Zealand workers' compensation scheme and its basic principles.

\section{Brief Overview of Workers' Compensation Schemes}

Before workers' compensation schemes were introduced injured or ill workers or their dependants received little, if any compensation, in spite of the horrendous rates of occupational injuries, diseases and fatalities. Often the only compensation workers and their families received was in the form of charity from their employer or the community. Substantial public collections were taken up after disasters involving significant worker fatalities, such as the 1896 Brunner Mine Disaster on the West Coast of New Zealand, but such support was restricted to highly visible incidents and even then financial assistance was by no means guaranteed (Campbell, 1996). Relying on employer or community sympathy and public charity left many injured workers, widows and orphans in poverty (Purse, 2005; Armstrong, 2008).

Better paid, usually skilled workers could however, take out a form of mutual insurance by joining a friendly society (such as the Oddfellows) or a trade union which offered sickness, funeral and other friendly or social benefits - a major function of many early unions. In $19^{\text {th }}$ century New Zealand mutual insurance was the most common form of protection insurance, but only the bestpaid workers, such as craftsmen, could afford it. But 
again seriously disabled workers would be impoverished by their injury. And only those with steady good paying jobs would be covered, because those who for whatever reason (such as temporary unemployment) could not afford to make payments would lose their cover (Lamm, 2008).

Injured workers tried to sue their employers in tort for intentional or negligent injury. The modern law of negligence arguably began in 1932 with the famous case of Donoghue v. Stevenson. The problem was, however, that workers rarely won when they tried to sue their employer in tort. During the 19th and early 20th centuries worker's tort claims were defeated by one or other legal doctrines (the so-called "unholy Trinity") namely: a) common employment; b) contributory negligence: and c) volenti non fit injuria (Purse, 2005). The first doctrine, common employment, rejects the liability for the employer on the basis of the negligence of a co-worker. Given the complexities of industrial production it was often easy to show that some employee or other negligence contributed to the worker's injuries. Of course one could and did argue that the employer had an overriding duty as master to ensure the safety of his servants based in the contract of employment, but the courts seemed willing to ignore the potential contractual obligations when faced with claims from injured workers. The second, doctrine, contributory negligence, meant that if the worker's own carelessness contributed to the accident then the employer could not be held liable for compensation. In New Zealand and the passage of the Contributory Negligence Act in 1947 liability could not be apportioned. The third doctrine, volenti non fit injuria, held that those who voluntarily undertook risky activities were assumed to have also voluntarily assuming the risks of injury. Under this doctrine, employees, like rugby players today. could not sue for injury which was a reasonably foreseeable as a likely risk of the work activity. It is understandable therefore that workers and their unions have been highly suspicious of the courts (Rennie, 1995; Armstrong, 2008)

The courts were not only hostile to workers for any number of reasons but also tort law was, by today's standards, quite unreceptive to negligence claims. Reasons for the courts' hostility to claims by injured workers in those days are these days seen as political. At the turn of the 20th Century judges shared with employers a belief in the importance of private property and the lower value, both socially and economically, of workers. The traditional rules regarding master and servant were enforced in ways that respected the managerial prerogatives of employers. Some judges may have sought to protect industry and thus employers from the economic costs of injured workers' claims, but they likely did so because they believed it wrong to penalize the employer who was providing work and thus wages for many workers for unforeseen and unintended accidental injury to one worker. It was better to impoverish the worker than to bankrupt the employer (Lamm, 2008).
Given the problems suing employers for compensation for injury or illness, it as not surprising that the introduction of workers compensation schemes was seen a blessing but came as a result of years of political struggle on the part of workers, unions and other interested parties. With workers' compensation schemes, injured workers had the benefit of an employer funded yet publicly run compensation scheme.

The first legislative workers' compensation scheme was introduced in Germany by Chancellor Bismarck in 1880 . Similar schemes were introduced in England in 1897 and over the next 30 years in Australia, the USA, Canada and New Zealand (Campbell, 1996; Cowan, 1997; Plumb and Cowell, 1998; Purse, 2005). With the establishment of workers' compensation, the legislation limited or removed the workers' right to sue their employer and established an administrative compensation scheme for injuries arising out of or in the course of employment. The legislation was often described as a bargain or compromise as workers gave up the right to sue their employer for damages in tort for their injuries in exchange for more certain and quicker "no fault" compensation administratively determined. Workers' compensation ceased to be a matter for the courts and new bureaucracies were born.

The extension of a no-fault, or absolute liability, scheme to include all individuals in New Zealand was first seriously mooted in 1928 as part of the parliamentary debate that accompanied the introduction of the Motor Vehicles Insurance (Third-party Risk) Act. Almost a decade later, New Zealand came nearer to achieving comprehensive no-fault legislation with a drafted Bill, but in the face of strenuous opposition it was dropped (Lamm, 2008). However, as comprehensive no-fault schemes were operating successfully in parts of Canada and the United States as early as 1946, the issue was again raised by some in the Labour Government. Many Labour politicians were of the opinion that as New Zealand was a signatory to ILO conventions concerning no-fault workers' compensation, the government had an obligation to apply the ILO absolute liability principle to New Zealand workers' compensation legislation. However, such a scheme was not popular among many motorists and efforts to bring about an absolute liability Bill in 1947 were blocked by the Member of Parliament for Palmerston North, who was prominent in the Automobile Association.

During the 1960s there was growing disquiet over the limitations of the workers' compensation scheme in which payments had fallen to $53 \%$ of the average weekly wage and which stopped altogether after six years even if the worker was quite incapacitated. In addition, the ILO Absolute Liability Workers' Compensation Convention 121, 1964, provoked considerable interest in New Zealand and inspired the Minister for Labour, the Hon. T.P. Shand to declare: 
I frankly believe that the time has come for the abolition of common law claims for accidents in industry, but before contemplating taking away that right we must make up our minds that the alternative compensation provided in workers' compensation legislation must be more generous, full, and fitting than it is today.

(Cited in Campbell, 1996: 42).

Two years later the Government appointed a Royal Commission, chaired by the Hon. Owen Woodhouse, a Supreme Court Judge, to investigate compensation for personal injury. Numerous submissions were heard and various countries were visited, and the resulting Woodhouse Report went beyond its terms of reference and proposed a universal 'no-fault' system based on the five guiding principles listed and discussed below ( $\mathrm{J}$. Woodhouse, Royal Commission to Inquire into and Report upon Workers' Compensation, 1967: 39).

1. Community responsibility. 'In the national interest, and as a matter of national obligation, the community must protect all citizens (including the self-employed) and the housewives who sustain them, from the burden of sudden individual losses when their ability to contribute to the general welfare by their work has been interrupted by physical incapacity.'

2. Comprehensive entitlement. 'All injured persons should receive compensation from any community financed scheme on the same uniform method of assessment, regardless of the causes which gave rise to their injuries.'

3. Complete rehabilitation. 'The scheme must be deliberately organised to urge forward the physical and vocational recovery of these citizens while at the same time providing a real measure of money compensation for their losses. '

4. Real compensation. 'Real compensation demands for the whole period of incapacity, the provision of income-related benefits for lost income and recognition of the plain fact that any permanent bodily impairment is a loss in itself, regardless of its effect on earning capacity.'

5. Administrative efficiency. 'The achievement of the system will be eroded to the extent that its benefits are delayed, or are inconsistently assessed, or the system itself is administered by methods that are economically wasteful.'

Finally, after much debate, Parliament incorporated the five Woodhouse principles into the 1972 Accident Compensation Act. The Act established, for the first time, a "no-fault" scheme that provides one source of compensation for personal injury, irrespective of who was at fault. The right to sue to recover compensatory damages arising directly or indirectly out of personal injury was abolished, although an action for damages could still be taken in a court outside New Zealand. In addition, the Act created the Accident Compensation
Commission (ACC) responsible for the administration of the scheme. The government also introduced an 'experience rating system' under the Accident Compensation Act whereby companies or the industry pay a levy according to the number of accidents that happen. This was in spite of the fact that it had been widely discredited by academics, practitioners and the Woodhouse Commission (Oliphant, 2004; Duncan; 2007). Woodhouse believed that a levy system could not operate equitably and that such financial incentives would be insignificant for any substantial organisation, relatively unimportant for a small one, and non-existent in the public sector. The Report also argued that such a system could be open to corruption

By the late 1980s and early 1990s, ACC was totally committed to the loss-control perspective. It developed safety management programmes and supported tertiary degrees in safety management (Campbell, 1997). Nevertheless, there was a steady call from employers particularly those in large businesses - to reduce workers' compensation costs (rather than bringing about a reduction in accidents, injuries and work-related diseases). In response, the newly elected National Government set about narrowing the compensation categories as a way of reducing the growing ACC debt and the employers' compliance costs. The legislation that followed, namely the Accident Rehabilitation Compensation Insurance Act 1992, was designed to contain the overall costs and reallocate them amongst taxpayers and individuals paying premiums. The principle means of doing this were:

- refocusing the scheme on its insurance origins, particularly by the use of experience rating and user part charges;

- realigning the scheme with new health care provisions to reduce the incentive to shift costs between illness and injury schemes;

- $\quad$ redistributing costs by allocating public health costs to the scheme and introducing a new earners' premium for non-work injuries, and

- containing costs by altering benefits and tightening scheme eligibility (for example, by abolishing lump-sum payments - this would gravely affect asbestos disease sufferers whose life expectancy is minimal) and unless physical injury was present, stress and mental injury were generally not covered.

Furthermore, the most controversial parts of the Act were the alterations to the definitions of accident, work injury, gradual process diseases and infection. The new definitions tightened the scope of claims accepted by the ACC as personal injury by accident. Claims for personal injuries could only be considered if the accident was a result of: 
a specific event external to the human body that results in personal injury but does not include any gradual process;

the application of an external force or resistance that is abnormal in application and/or excessive in intensity.

Narrowing the compensation categories as a way of restricting compensation entitlements generated widespread criticism (Armstrong, 2008). More changes were to come, however. In the late 1990s, ACC allowed accredited employers to manage their claims for up to two years. There was also a distinct policy shift by ACC to reduce the number of long-term ACC claimants. Each person with a significant injury became the responsibility of an individual ACC staff member and greater emphasis was placed on rehabilitation and returning injured workers back into the workforce. The effort by ACC to purge itself of long-term claimants, such as those involving occupational over-use injuries, set the scene for the introduction of private insurers into the workers' compensation market. Moreover, the National Government was keen to introduce competition into the state-run workers' compensation scheme and enacted the Accident Insurance Act in 1998. In effect, the government disengaged itself from workers' compensation altogether by creating a new Crown-owned enterprise in late 1998 specifically for workplace injury insurance, called@Work Insurance (for more details, see Lamm, 2008).

However, just as New Zealanders were coming to grips with the new legislation there was a change of government at the end of 1999 in which the LabourAlliance Coalition Government introduced Injury Prevention, Rehabilitation, and Compensation Act, 2001.

The Injury Prevention, Rehabilitation, and Compensation Act, 2001 differs from previous law in that it establishes injury prevention as a primary function of Accident Compensation Corporation. The Act specifies a new rehabilitation principle - namely, that rehabilitation is to be provided by the Corporation to restore the claimant's health, independence and participation to the maximum extent practicable and can make available a lump-sum payment for permanent impairment. The intent of this change is to provide fairer compensation for those who, through impairment, suffer non-economic loss. This includes both physical impairment and mental injury (caused by a physical injury or sexual abuse). The Act further provides: a more flexible assessment of loss of earnings; a new formula for setting a minimum level of weekly compensation; more flexible provisions for selfemployed people, and simplified regulations concerning premium payment procedures. The Act also incorporates a Code of ACC Claimants' Rights as well as allowing for the disclosure of information to the Department of Child, Youth and Family Services and for the reporting of medical errors to the relevant professional body and the Health and Disability Commissioner.
Since 2001, there have been a number of amendments to, such as extending the no fault principle to medical misadventure and compensation for self-employed as well as greater discretion for rehabilitation. The amendment to the Act also bypasses the normal requirement to prove causation which is required for gradual process injuries or diseases. It also lists 25 additional conditions or diseases to be added to Schedule 2. Although many of the occupational diseases are rare, some are more common, such as noise induced hearing loss, dermatitis and some types of asthma caused by sensitizing agents or irritants inherent in the work process, for example sawdust (Accident Compensation Corporation, 2005). This change will have the greatest affect on industries where employees may be exposed to the risk of certain diseases.

In summary, in the past century workers' compensation legislation has addressed, more or less, the issues relating to compensation, rehabilitation and prevention. Over the last thirty years the domain of workplace safety has been bifurcated as issues relating to the prevention of workplace injury and disease have been largely removed from the purview workers' compensation and placed into the domain of occupational health and safety.

\section{"A Modest proposal" (Swift, 1729)}

However, as stated above, after a century of the same basic workers' compensation structure, it may be time to consider ending the workers' compensation experiment. The stark truth is that after centuries of industrialization, every year hundreds of workers are still maimed and killed while working in New Zealand. Moreover, while the Woodhouse tenets are laudable, the fact is that his vision has been so corrupted that it could be argued that New Zealand's workers' compensation scheme no longer affords workers with comprehensive, real compensation and rehabilitation and it is time to rethink another strategy. The three key reasons for change in workers' compensation are as follows.

First, the levels of compensation offered under workers' compensation are too low. Over the past century the amounts of compensation offered by workers' compensation schemes have declined (Turner, 2006). At the beginning workers' compensation was clearly a better option than no workers' compensation. However, since the 1960's the levels of compensation for workplace injuries and disease, when compared to compensation offered to victims of automobile or environmental injury, have worsened. In many jurisdictions not only do injured workers receive much less than similarly injured drivers, but also the amount of compensation leaves them and their families in poverty. Thus, the argument can be made that these days workers are bearing an unreasonable burden of the cost of workplace injury and disease as successive governments continue to reduce compensation. Medical coverage, for example, often provides for only limited medical services (such as short 
periods of physiotherapy treatment or psychological counselling).

Short-term income replacement is usually set at less than $100 \%$ of lost wages the rationale being that the injured workers have an 'incentive' to get back to work more quickly (Rosenman, 2000; , arrish and Schofield, 2005; Thompson, 2007). Moreover, long-term compensation rarely includes compensation for the impact of serious injury on a person's life as few schemes include compensation for loss of amenities of life which would take into account the impact of such injuries on one's ability to live life to the fullest - and longest (Quinlan, 2004).

Linked to the argument that the levels of compensation offered under workers' compensation are too low is that workers' compensation has become too expensive to be economically feasible (Sengupta, et al 2005). Indeed, similar arguments are used in the debate around public versus private health systems. The issue of costs incurred in operating a workers' compensation scheme raised by employers and by unions and workers are important but are often tied to ideology rather than fact. The pressure by employer associations to have the ACC privatised in whole or in part is predicated on the view that the marketplace can deliver a more cost efficient service. They point to rising workers' compensation levies yet do so often without making the connection between the rise in costs and the rise in work-related injuries. Interestingly, the Australians lament the fact that they never adopted the New Zealand workers' compensation system and instead have inherited their costly, complex and confusing private/public sector split (see for example Australian Productivity Commission Inquiry Report, 2004). Trade unions on the other hand are concerned over efforts to reduce employer levies and manipulate the number of claims in order to present a better financial view of ACC. The CTU argues that reduced compensation and rehabilitation shifts the costs from the ACC and the employer to the worker. Representatives of the CTU add that it is a conflict of interest to have employers managing employee injuries which are caused at the workplace and are linked to employer insurance premium

Second, tort law would provide better compensation. Not only has workers' compensation undergone radical changes, but so has tort law (Wood, et al, 1995). Since workers' compensation was introduced in the late 19th Century, the common law has also continued to evolve. In the 1930's and the case of Donoghue v. Stevenson, the tort negligence has emerged as an effective tool to deal with complexities of injuries in all areas of modern life, yet is seen as not suitable to apply to the workplace. The reasoning behind the treating workers differently is reliant on a characterization of the workplace as the private domain of the employer and the view that the employment relationship as one master and servant. While tort law as it was in 1900 may have protected employers from workers' claims, it is unlikely that tort law of 2009 would do the same. There is of course the concern that tort law is too slow, cumbersome and that the outcome is uncertain. But if sufficient resources are given to the courts, workers' compensation cases could be heard and resolved quickly allowing both successful and unsuccessful claimants to progress (for example, unsuccessful claimants could seek other government redress) instead of being in an indeterminate state. In short, the view perpetuated for over half a century that workers' compensation is a better option for workers, based on the historical comparison between workers' compensation and tort, needs to be revisited as benefits of tort law have clearly been increasing while the benefits of obtaining workers' compensation has worsened over the past 50 years

Third, tort liability would enhance prevention. In New Zealand workplace fatalities is high compared to most OECD countries, as outline in table 1 and yet compliance with occupational health and safety regulations is low. Moreover, enforcement resources have steadily declined over the past 20 years, leaving New Zealand with one of the lowest ratios of inspectors to workplaces in the OECD countries. As a result workplace hazards have become increasingly difficult to monitor and police. It is argued that a return to tort would enhance prevention by acting as an economic deterrence (see Lamm, 2002). That is, employers would have increased incentive to ensure safe and healthy work place as the financial consequences of injured workers' suits would be unpredictable. The aspects of tort which lead it to be seen as a lottery could be minimized by regulation. For example, all employers could be required to carry insurance for workplace injury and for workers to carry no fault insurance if they so desired as is the case for motorisis in most Canadian provinces. A return to tort would also assist in allowing compensation for workplace injury and disease to develop. The courts would, in effect, provide a public forum in which scientific evidence of new forms of injury and diseases could be weighed and determined. In short, the common law through tort would provide a better, more flexible and fairer process for determining the rights of injured workers and their employers.

Table 1: Workplace Fatalities across Countries

\begin{tabular}{|l|c|c|c|}
\hline Country & Fatalities & $\begin{array}{c}\text { Fatalities } \\
\text { Rate per } \\
100.000 \\
\text { workers }\end{array}$ & $\begin{array}{c}\text { Accident } \\
\text { Rate per } \\
100.000 \\
\text { workers }\end{array}$ \\
\hline Australia & 275 & 3.2 & 2434 \\
\hline Denmark & 90 & 3.4 & 2561 \\
\hline New Zealand & 61 & 3.5 & 2699 \\
\hline Norway & 72 & 3.2 & 2446 \\
\hline Sweden & 77 & 1.9 & 1469 \\
\hline United Kingdom & 225 & 0.8 & 632 \\
\hline United States & 6821 & 5.2 & 3959 \\
\hline
\end{tabular}


Similar questions are asked with respect to accidents and diseases involving motorists and consumers. And while in New Zealand all those injured by accident receive the same level of compensation, in other Anglo American jurisdictions levels of compensation for non work related injury is higher. Arguably, workers (and in New Zealand all of the injured) are subsidizing unsafe and unhealthy workplaces. To the extent that there is not full compensation, the costs of work related injury and disease are shifted from the employer to the worker, from the commercial enterprise to the worker's family and community. Surely it must be asked at some point, why, if the ACC system is so efficient and cost effective, are compensation levels so much lower than in New Zealand. What part of the savings have been passed on to the injured?

\section{Conclusions}

As the debate over the future of workers' compensation both here in New Zealand and overseas continues, it may be time to ask new questions. Any proposed reform needs to be judged in the light of the principles set out by Woodhouse. So when the employers propose, as they always do, that costs be controlled, workers and unions might ask about fair compensation. When employers' demands include private insurance, then workers' demands should also include choice - the right to be covered by an insurer of their choosing. And when the levels of compensation no longer provide complete rehabilitation and the administrative process no longer allows for fair and speedy adjudication and appeal, then the question has to be. "Why workers' compensation?" If the system is not meeting the needs of employers and is not fairly compensating injured and sick workers, then why not get rid of it?

\section{References}

Armstrong, H. (2008), Blood on the Coal: The origins and future of New Zealand's Accident Compensation Scheme, Trade Union History Project, Wellington: www.tuhp.org.nz.

Australian Productivity Commission Report, (2004). National Workers Compensation and Occupational Health and Safety Frameworks: Productivity Commission Inquiry Report No. 27, 16 March 2004. Melbourne: Commonwealth of Australia.

Bohle, P. and Quinlan, M. (2000). Managing Occupational Health and Safety: A Multidisciplinary Approach. Sydney: Macmillan.

CampbelI, I. B. (1996), Compensation for personal injury in New Zealand: Its rise and fall. Auckland: Auckland University Press.
Duncan, G. (2007), 'Boundary Disputes in ACC and the No-Fault Principle' Accident Compensation: Forty years on - Symposium to Celebrate the Woodhouse Report. Auckland University Law School

www.auckland.ac.nz/uoa/about/research/units/acc group/accgroup.cfm

Lamm, F. (2008), 'Occupational Safety and Health', in Rasmussen, E. (ed) Employment Relations in New Zealand. (2nd ed.). Auckland: Prentice Hall.

Lamm, F. (2002) 'OHS in Small Businesses' in Lloyd, M. (ed) Occupational Health and Safety in New Zealand: Contemporary Social Research. Dunmore Press: Wellington.

Oliphant, K. (2004), 'Beyond Woodhouse: Devising New Principles for Determining ACC Boundary Issues', Victoria University of Wellington Law Review, 35(4): 915-936

Parrish, M. and Schofield, T. (2005), 'Injured Workers' Experiences of the Workers' Compensation Claims Process: institutional disrespect and the neoliberal state', Health Sociology Review, 14(1): 33-46

Purse, K. (2005), 'The Evolution of Workers' Compensation Policy in Australia', Health Sociology Review, 14(1): 8-20.

Quinlan, M. (2001), 'Workplace Health and Safety Effects Of Precarious Employment' The Global Occupational Health Network, 2: 1-4

Quinlan, M. (2004), 'Workers' Compensation and the Challenges Posed by Changing Patterns of Work: Evidence from Australia' Policy and Practice in Health and Safety, 2(1): 25-52.

Rennie, D. (1995), 'Compensation for Work-related Injury' in Slapendel, C. (ed) Health and Safery in New Zealand Workplaces. Palmerston North: Dunmore Press,

Rosenman, K., Gardiner, J., Wang, J., Biddle, J., Hogan, A., Reilly, M., Roberts K, and Welch, E. (2000), 'Why Most Workers with Occupational Repetitive Trauma Do Not File for Compensation', Journal Occupational Environmental Medicine, 42(1): 25- 34.

Sengupta, I., Reno, V., Burton, J.F. (2005), Workers' Compensation: Benefits, Coverage, and Costs, 2003. Washington, DC: The National Academy of Social Insurance,

Thompson, A. (2007), 'The consequences of underreporting workers' compensation claims' 
Canadian Medical Association Journal, 176(3): 343-343.

Turner, J. (2006) 'All in a Day's Work? Statutory and Other Failures of the Workers' Compensation Scheme as Applied to Street Corner Day Laborers' Fordham Law Review, 74: 1521-1556.

Wood, G., Morrison, D., Harrison, J., and MacDonald, S. (1995), 'The Determination of Common Law Awards to Injured Workers', The Australian Economic Review, 4th Quarter.

Woodhouse, Sir Owen, (1967) Compensation for Personal Injury in New Zealand: Report of the Royal Commission of Inquiry. Wellington: Parliament.
Author

Nadine McDonnell

Lecturer

School of Business - Business Research Auckland University of Technology Private Bag 92006

Auckland 1142

Nadine.McDonnell@aut.ac.nz 